\title{
CMA developing assisted death guidelines
}

$\mathrm{T}$ he Canadian Medical Association (CMA) was given the green light by delegates to the association's General Council on Aug. 26 in Halifax to develop guidelines for assessing patients who request physician-assisted death.

Doctors are preparing for the prospect that there may be no legislation to guide them when criminal sanctions on physician-assisted dying are lifted next year. Canada's top court overturned the ban on medical aid in dying earlier this year, giving federal and provincial legislatures until Feb. 6, 2016, to draft new laws. The court set out that physicianassisted death should be allowed for competent adults who have a "grievous and irremediable condition" that causes intolerable suffering.

This leaves considerable leeway for interpretation, and although federal and provincial panels have been set up to look at the issue, the job of interpreting legislation may well fall to physicians.

"We don't want to arrive on Feb. 6 asking ... does anyone know how to do it? Does anyone know who qualifies?" said Dr. Chris Simpson, outgoing CMA president, in an Aug. 25 press conference. "The worst-case scenario is the complete absence of any federal legislation" resulting in a "patchwork quilt" of provincial and territorial regulations, he said. "This is hard enough as it is; the last thing we want is 10 different sets of rules."

Also passed at General Council were motions supporting consultation with the Canadian Society of Palliative Care Physicians and advocacy for better access to palliative care.

Conscientious objection was a contentious issue, with $79 \%$ of delegates voting against a motion to support conscientious objectors who refuse to refer patients for medical aid in dying.

"What we expect from physicians, at a minimum, is that they provide further information to patients on all the options including the spectrum of end-of-life care and ... how to access those ser-

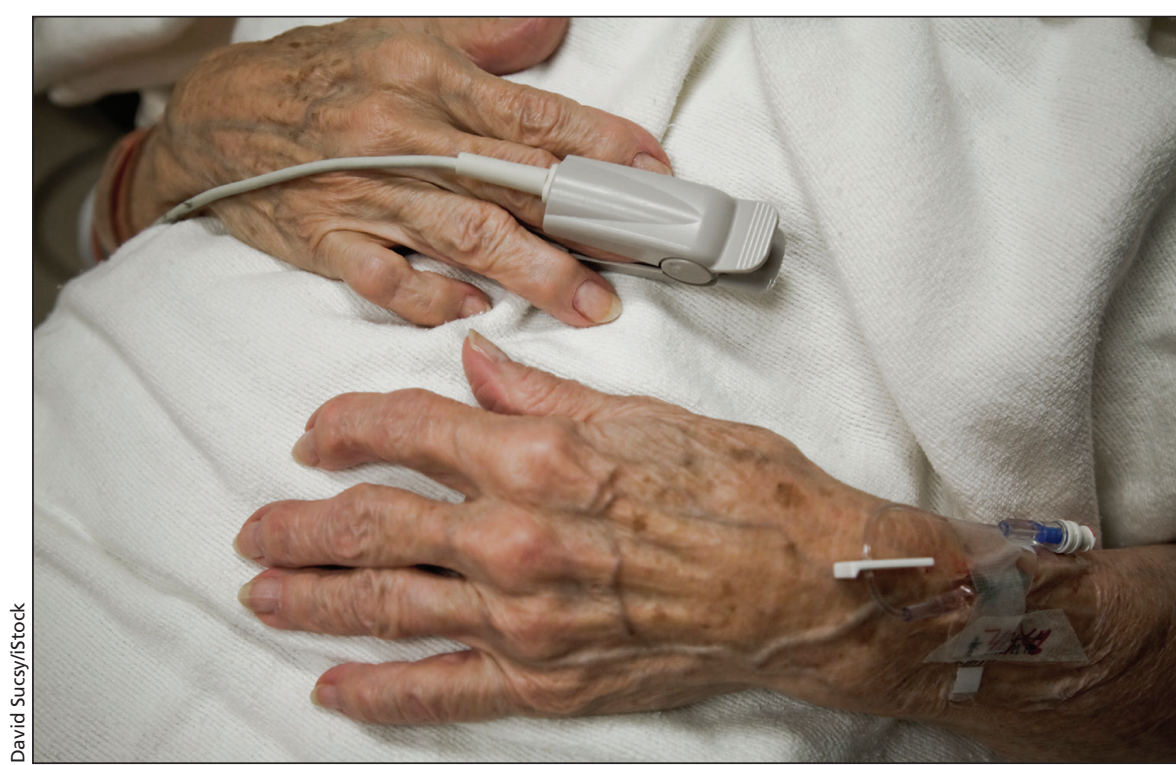

Doctors are making contingency plans as federal action on assisted dying stalls before the election.

vices," CMA Vice President of Medical Professionalism Dr. Jeff Blackmer told reporters at a press conference Aug. 26.

Based on discussions at the meeting, Simpson said yesterday that CMA will seek a "solution that will not force physicians to participate in assisted dying against their moral or religious beliefs, while making sure that access is available for patients who qualify."

CMA is also working on developing a two-day course to teach physicians about physician-assisted dying. "There's a lot of complexity to this for Canadian doctors and it's the first time any of us can remember being forced to undertake a new intervention without any training or experience," said Blackmer. He noted that he's still "not sure whether we will be ready to help people with assisted dying on Feb. 7."

As it stands, it's not clear the federal government will be ready either, said Simpson. "We're very concerned time is running out."

\section{Federal response}

Federal opposition parties have criticized the former Conservative government for dragging its feet on the issue.
Shortly after the Supreme Court ruling in February, the Liberals called for the creation of a multiparty special committee to propose a framework for a new law by mid-summer. The Conservatives voted against the motion and waited until July to appoint an expert panel. The federal panel is not expected to report back until after the Oct. 19 election, at which point a new government will be tasked with drafting legislation.

Assisted dying advocates have also raised concerns that the three-member federal panel is composed of individuals who have publicly declared opposition to medical aid in dying. The panel's chairman is psychiatry professor Dr. Harvey Max Chochinov, the Canada research chair in palliative care at the University of Manitoba. His copanelists are University of Ottawa law professor Benoît Pelletier and Catherine Frazee, former co-director of the RBCRyerson Institute for Disability Studies Research and Education in Toronto. Others have argued that assisted dying ought to be an election issue, although all parties seem equally unwilling make it so. 
Arthur Schafer, director of the Centre for Professional and Applied Ethics at the University of Manitoba, says that the makeup of the federal expert panel and how parties have voted in the past should provide enough clues where each will stand.

"It's pretty clear that the Conserva- tives, although they won't talk about it, are opposed and the Liberals and New Democrats, although they won't talk about it, are in favour," he says. But even in absence of federal legislation, the provinces may yet cooperate on pan-Canadian regulation.

Ontario formed its own expert panel earlier this month, and for now "all provinces are participating," says Schafer, who will advise on ethics. The panel is beginning deliberations and expects to release a report in December. — Lauren Vogel, CMAJ

CMAJ 2015. DOI:10.1503/cmaj.109-5142 